\title{
Comparison of heavy metals from resident Larus dominicanus and migratory Leucophaeus pipixcan collected in Talcahuano, Chile
}

\author{
Comparación de metales pesados en la gaviota residente Larus dominicanus y la gaviota migratoria \\ Leucophaeus pipixcan colectadas en Talcahuano, Chile
}

\author{
M Sepúlvedaa ${ }^{\mathrm{a}}$ D Gonzalez-Acuña ${ }^{\mathrm{b}^{*}}$

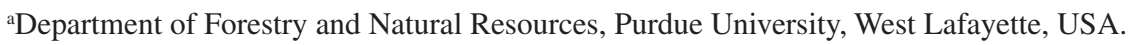

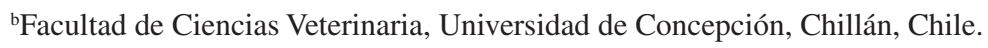

\begin{abstract}
SUMMARY
In this study we present data on heavy metal concentrations in feathers from two Chilean sea gull species: the resident kelp gull $(\mathrm{n}=54)$ and the summer visiting Franklin's gull (59) sampled between 2008 and 2009. Average $\pm \mathrm{SD}$ concentrations for $\mathrm{As}, \mathrm{Cd}, \mathrm{Cu}, \mathrm{Pb}$, and $\mathrm{Hg}$ were of $0.75 \pm 0.21$, $0.03 \pm 0.04,19.5 \pm 1.7,5.9 \pm 6.0$, and $1.1 \pm 0.1 \mu \mathrm{g} / \mathrm{g}$ for the kelp gull and of $0.764 \pm 0.37,0.15 \pm 0.20,4.1 \pm 1.7,2.6 \pm 5.5$, and $1.2 \pm 0.2 \mu \mathrm{g} / \mathrm{g}$ for Franklin's gulls. These values are comparable to those reported for these species sampled in Chile and other places and are below levels known to cause adverse effects in seabirds. Differences in metal concentrations between species are likely due to differences in diet and timing of sampling in relation to molting.
\end{abstract}

Key words: heavy metal, contamination, kelp gull, Franklin gull, molting.

\section{RESUMEN}

En el presente estudio presentamos información sobre la concentración de metales en plumas de dos especies de gaviotas de Chile: la gaviota residente gaviota dominicana $(\mathrm{n}=54)$ y la visitante estival gaviota de Franklin $(\mathrm{n}=59)$. Las aves fueron muestreadas en Chile central en diferentes tiempo durante el 2008 y 2009. Concentraciones promedios $\pm \mathrm{SD}$ para $\mathrm{As}, \mathrm{Cd}, \mathrm{Cu}, \mathrm{Pb}, \mathrm{y} \mathrm{Hg}$ fueron de $0,75 \pm 0,21,0,03 \pm 0,04,19,5 \pm 1,7,5,9 \pm 6,0, \mathrm{y}$ $1,1 \pm 0,1 \mu \mathrm{g} / \mathrm{g}$ para la gaviota dominicana y de $0,764 \pm 0,37,0,15 \pm 0,20,4,1 \pm 1,7,2,6 \pm 5,5, \mathrm{y} 1,2 \pm 0,2 \mu \mathrm{g} / \mathrm{g}$ para la gaviota de Franklin. Estos valores son comparables a los registrados tanto en Chile como en otras partes y están bajo los niveles que producen efectos adversos en las aves. Diferencias entre las concentraciones de metal son debidas a diferentes dietas y tiempos de muestreo lo que se relaciona con el proceso de muda.

Palabras clave: metal pesado, contaminación, gaviota dominicana, gaviota Franklin, muda.

\section{INTRODUCTION}

Seabirds have several characteristics that make them ideal sentinel species for monitoring marine environments for the presence and potential impacts of pollutants. First, they have long life spans and are usually top predators making them likely to bioaccumulate pollutants. Secondly, their feathers and eggs can be sampled non-destructively for quantification of pollutants. And thirdly, the ecology and physiology of many seabirds is well known which greatly facilitates interpretation of tissue contaminant data (ICES 1999).

Feathers are particularly useful for monitoring exposure to heavy metals. This is because metals translocate from the blood preferentially binding to the sulfur groups of keratin proteins as feathers grow (Burger 1996, Burger and Gochfeld 1997). However, metals will only translo-

Accepted: 03.10.2013.

* Casilla 537, Chillán, Chile; danigonz@udec.cl cate to growing feathers because once mature, communication with the blood stream is halted. This has important implications for determining timing and location of exposure, particularly in migratory birds.

Although the kelp gull Larus dominicanus has a wide geographic distribution in the southern hemisphere, including southern South America, the Antarctic, Australia, New Zealand, and South Africa, populations are not migratory. In contrast, every year the Franklin's gull Leucophaeus pipixan migrates long distances from North America where it breeds (April) in relatively undisturbed prairie marshes (Burger 1974) to its wintering grounds in coastal South America. Franklin's gulls prey on small fish and marine invertebrates in their wintering grounds and on earthworms and insects during the breeding season $^{1}$. The kelp gull is mostly piscivorous and it is known

Burger J, M Gochfeld. 2009. Franklin's Gull (Leucophaeus pipixcan). In: Poole A (ed). The Birds of North America Online. Ithaca, Cornell Lab of Ornithology. http://bna.birds.cornell.edu/bna/species/116 
for feeding on discarded food from fishing vessels and human-derived waste (Petracci et al 2004, GonzálezZeballo 2006).

The objective of this study was to quantify heavy metal exposure in the Kelp and Franklin's gulls sampled from central Chile. Because Franklin's gulls breed in inland lakes far from urbanised and industrialised areas we hypothesised that kelp gulls would contain higher concentrations of heavy metals due to their sedentary residency located in a highly urbanized area in central Chile. We also hypothesised that females would contain less metal concentrations compared to males due to transfer to eggs, and that there would be a significant positive relationship between body size and heavy metal concentrations. We were also interested in determining whether metal concentrations would be high enough to potentially harm these populations. This is the first study that compares heavy metal concentrations between these two gull species and one of several that have examined heavy metals in Chilean marine birds (Vermeer and Castilla 1991, Muñoz and Becker 1999, Ochoa-Acuña et al 2002, Cifuentes et al 2003, Cortés and Luna-Jorquera 2011).

\section{MATERIAL AND METHODS}

\section{SAMPLE COLLECTION}

This study was conducted in the city of Talcahuano in south central Chile ( $36^{\circ} 43^{\prime} 0^{\prime}$ ' S, $73^{\circ} 7^{\prime} 0^{\prime \prime} \mathrm{W}$ ). Resident adult kelp gulls $(n=54)$ and summer visiting Franklin's gulls $(n=57)$ were sampled in 2008 and 2009. Franklin's gulls were sampled between mid-January to mid-April, which represents the end of the molt period after their migration from North America (figure 1A). Thus heavy metal concentrations measured in March/April from Franklin's gulls are mostly the result of exposure in Central Chile. In contrast, heavy metal concentrations from the January samples represent exposure occurring in North America prior to their migration. Kelp gulls were sampled in March and April, early August and early October which covers the fall and winter period in between molts (figure 1B). Both species molt twice annually (see figure 1).

Birds were collected using four different methods as described in Gonzalez-Acuña et al (2010). Once captured, birds were measured, weighed and feathers were collected for heavy metal analyses. Primary feathers (numbers 8, 9 and 10; Jaramillo 2005) were collected from all birds with the exception of Franklin's gulls sampled in January. Since this group of birds was not sacrificed a handful of body covert feathers were collected instead. Therefore, metal concentrations reported here were mostly quantified from a single primary feather, with exception of Franklin's gulls sampled in January from which a pool of 5-10 body covert feathers was used instead.

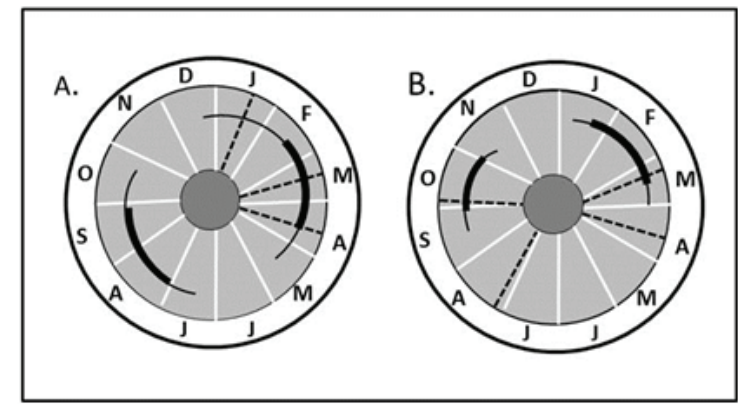

Figure 1. Molting cycle for each species. (A) Franklin's gull Leucophaeus pipixcan and (B) kelp gull Larus dominicanus. The black lines inside the grey circle denotes molting and the dashed lines indicate feather collection times. Both species are reported to molt twice annually. Letters denote months. Mercury was the only metal measured in January for Franklin gulls and in October for kelp gulls. Adapted from Kinsky FC (1963) and Burger and Gochfeld (2009). Seasons (southern hemisphere): 22 December - 21 March, summer; 22 March - 21 June, fall; 22 June - 21 September, winter; and 22 September - 21 December, spring).

Ciclo de muda para cada especie. (A) Gaviota de Franklin Leucophaeus pipixcan y (B) gaviota dominicana Larus dominicanus. Líneas negras dentro de los círculos grises denota la muda y las líneas entrecortadas indican el momento en que las plumas fueron colectadas. Ambas especies mudan dos veces al año. Letras indican meses. Mercurio fue el único metal detectado en enero en las gaviotas de Franklin y en octubre en las gaviotas dominicanas. Adaptado de Kinsky FC (1963) y Burger y Gochfeld (2009). Temporadas (hemisferio sur): 22 diciembre - 21 marzo, verano; 22 marzo - 21 junio, otoño; 22 junio - 21 septiembre, invierno; y 22 septiembre -21 diciembre, primavera).

\section{HEAVY METAL ANALYSIS}

Feathers were analysed for the following heavy metals: Arsenic (As), cadmium (Cd), copper $(\mathrm{Cu})$, total mercury $(\mathrm{Hg})$ and lead $(\mathrm{Pb})$. Overall, $\mathrm{Hg}$ was analysed in all of the birds sampled which included March through August $(n=23)$ and October $(n=31)$ of 2008 for kelp gulls and January $(n=13)$ and March through April $(n=46)$ for Franklin's gulls, 29 of which were collected in 2008 and the rest in 2009. Only a subset of these samples was analysed for the remaining metals which included 21 kelp and 24 Franklin's gulls sampled in the summer/fall (March, April and August and March and April, respectively). For the $\mathrm{Hg}$ analysis, feathers were rinsed with deionised water, cut with clean scissors and weighed to the nearest $0.01 \mathrm{~g}$ in nickel boats. Samples were then analysed for total $\mathrm{Hg}$ concentrations using thermal decomposition, amalgamation/atomic absorption spectrophotometry (TDA/AAS, DMA-80, Milestone, Inc., Monroe, CT, USA) as described in Lasrado et al (2005) and following EPA method 7473 (USEPA 2003). The instrument was calibrated with lobster hepatopancreas (TORT-2, National Research Council, Ottawa, Ontario, Canada). TORT-2 was used to calibrate cell 1 of the instrument at 
0.01 to $35 \mathrm{ng}$ so that the limit of detection was $0.1 \mu \mathrm{g} / \mathrm{g}$. Nickel boats (same as used for weighing samples) were then loaded onto the DMA-80 analyser.

The remaining metals $(\mathrm{As}, \mathrm{Cd}, \mathrm{Cu}$ and $\mathrm{Pb}$ ) were quantified in a subset of birds ( 21 and 24 for kelp and Franklin gulls, respectively) using a ThermoFinnigan ELEMENT2 (FinniganMAT, San Jose, CA, USA; Bremen, Germany) inductively coupled plasma mass spectrometer (ICP-MS) in the medium resolution mode. Feathers were first rinsed with $100 \%$ acetone to remove any external contaminants and then dried in an oven for thirty minutes at $70{ }^{\circ} \mathrm{C}$. Once dried, a two inch section from near the tip of the feather on the trailing edge was cut using clean scissors. The portion that was removed from the feather was weighed and a sample of $10 \mathrm{mg}$ ( $\pm 0.4 \mathrm{mg}$ ) was placed in a $15 \mathrm{~mL}$ plastic tube (Corning, Lowell, MA, USA). Five milliliters of $70 \%$ trace metal grade nitric acid $\left[\mathrm{HNO}_{3}\right]$ (VWR, Radnor, PA) was then added and tubes were placed in a heating block at $70^{\circ}$ C for 12 hours, until all solids were visibly digested. The concentration of $\mathrm{HNO}_{3}$ was diluted to a $2 \%$ solution using Milli-Q grade water. Metals were quantified using a standard addition procedure. A standard addition curve was created for each species of gull using four reference points: blank or $0 \mu \mathrm{g} / \mathrm{L}\left(5 \mathrm{~mL} 2 \% \mathrm{HNO}_{3}\right) ; 1 \mu \mathrm{g} / \mathrm{L}(3.9 \mathrm{~mL}$ $2 \% \mathrm{HNO}_{3}+1 \mathrm{~mL}$ "unknown" sample $+100 \mu \mathrm{L}$ heavy metal multi-standard (containing $\mathrm{Cu}, \mathrm{As}, \mathrm{Cd}$ and $\mathrm{Pb}$ among others; Merck, Whitehouse Station, NJ, USA.); $5 \mu \mathrm{g} / \mathrm{L}$ (3.5 mL 2\% $\mathrm{HNO}_{3}+1 \mathrm{~mL}$ "unknown" sample $+500 \mu \mathrm{L}$ heavy metal multi-standard); and an "unknown" (1 mL sample $+4 \mathrm{~mL} 2 \% \mathrm{HNO}_{3}$ ). Once the standard addition curve was made, each of the heavy metals being examined were compared to the multi-standard and the blank to observe where individual samples fell into place on the scale of the perceived "zero" concentration of the blank and the perceived "maximum" concentration of the heavy metal multi-standard. Samples were introduced into the plasma using an Aridus desolvating system with a T1H nebulizer (Cetac Technologies, Omaha, NE, USA), which is used to enhance sensitivity and reduce oxide and hydride interferences. The argon sweep gas and nitrogen was adjusted for maximum peak height and stability using $7 \mathrm{Li}, 115 \mathrm{In}$ and $238 \mathrm{U}$ peaks obtained from the Merck multi-element standard ( $1 \mathrm{ng} / \mathrm{mL})$. Blank and standard samples were run at the beginning, in the middle and at the end of the runs to ensure that the instrument settings had not changed.

\section{DATA ANALYSIS}

Heavy metal concentrations were compared between species and within each species between genders and seasons using ANCOVA with body weight as the covariate (SAS 9.1). This was done because a significant positive relationship was observed for both species between body weights and metal concentrations for all metals under study. Heavy metal concentrations were log-transformed prior to these analyses. Significant differences were set at $\alpha=0.05$.

\section{RESULTS}

A summary of body measurements is presented in table 1 . As expected, kelp gulls were almost twice as heavy and significantly larger for all measurements compared to Franklin's gulls. Gender differences were only observed in kelp gulls with males being significantly larger than females.

A summary of metal concentrations for both species is presented in table 2 . The only species differences were observed for $\mathrm{Cu}$ and $\mathrm{Pb}$. For both metals, kelp gulls had higher concentrations compared to Franklin's gulls ( $\sim$-fold and 2-fold higher for $\mathrm{Cu}$ and $\mathrm{Pb}$, respectively). In terms of gender differences, male kelp gulls contained higher concentrations of $\mathrm{Hg}$ compared to females.

\section{DISCUSSION}

We speculated that feathers grown in Chile would contain higher metal concentrations compared to those grown in North America. For $\mathrm{Hg}$, the only metal that could be compared between sampling periods, this was not the case since the January samples contained similar concentrations compared to those sampled in March/ April $(1.1 \pm 0.8$ vs $0.87 \pm 1.1 \mu \mathrm{g} / \mathrm{g})$.

Several differences in feather metal concentrations were observed between the two gull species. $\mathrm{Cu}$ and $\mathrm{Pb}$ were $\sim 5$ times and twice the concentration, respectively in kelp gulls compared to Franklin's gulls. Cd was the only metal found at higher (five-fold) concentrations in Franklin's gulls and no significant differences were observed between species for $\mathrm{Hg}$ and As (table 2). Metal levels in feathers reflect circulating blood levels at the time the feathers were being formed and are the result of exposure (ingestion, inhalation) plus mobilization from tissues, minus tissue accumulation (other than feathers), excretion and metabolism (Burger 1996). Thus differences in feather concentrations between species could be the result of differences in exposure (or uptake) and/or differences in kinetics. Interspecific differences could also result from differences in mobility and migration behavior.

It is difficult to determine whether species differences in our study were due to differences in diet and/or to differences in kinetics. The kelp gull is a generalist that preys mostly on fish, but it is also known to eat fish discarded from fishing vessels (which could include large, pelagic species) and other discarded food items and waste found in garbage, whereas Franklin's gulls feeds mostly on marine invertebrates (mollusks and crustaceans) (Weichler et al 2004, Ludynia et al 2005, Villablanca et al 2007, Marinao and Yorio 2011). Assuming that the metal kinetics is similar in both species, differences are likely 
Table 1. Summary of body measurements by gull species, season and gender. Lower case letters denote significant differences between species and upper case letters denote significant differences between genders within species. No differences were detected between seasons. *Gulls sampled during the summer were not sacrificed so gender could not be determined. In addition, these were not primary feathers but body covert feathers.

Resumen de medidas corporales, por especie de gaviota, temporada y sexo. Letras minúsculas denotan diferencias significativas entre especies y letras mayúsculas entre sexos para cada especie. Ninguna diferencia fue observada entre temporadas. * Las gaviotas muestreadas en el verano no se sacrificaron por lo cual no se pudo determinar el sexo. Además, plumas en este muestreo correspondieron a plumón y no primarias.

\begin{tabular}{|c|c|c|c|c|c|}
\hline Species & Body Weight (g) & Tarsometatarsus $(\mathrm{cm})$ & Wing $(\mathrm{cm})$ & Beak (cm) & Tail $(\mathrm{cm})$ \\
\hline \multicolumn{6}{|c|}{ Larus dominicanus } \\
\hline Females (25) & $753 \pm 12^{\mathrm{A}}$ & $6.1 \pm 0.08^{\mathrm{A}}$ & $5.3 \pm 0.04^{\mathrm{A}}$ & $40 \pm 0.6^{\mathrm{A}}$ & $15 \pm 0.5$ \\
\hline Males (29) & $916 \pm 8.9^{\mathrm{B}}$ & $6.7 \pm 0.10^{\mathrm{B}}$ & $5.7 \pm 0.07^{\mathrm{B}}$ & $42 \pm 0.3^{\mathrm{B}}$ & $15 \pm 0.6$ \\
\hline Fall (23) & $841 \pm 22$ & $6.4 \pm 0.09$ & $5.5 \pm 0.08$ & $41 \pm 0.5$ & $14 \pm 0.6$ \\
\hline Spring (31) & $840 \pm 16$ & $6.5 \pm 0.11$ & $5.5 \pm 0.07$ & $42 \pm 0.5$ & $16 \pm 0.5$ \\
\hline Overall (54) & $840 \pm 13^{\mathrm{a}}$ & $6.4 \pm 0.08^{\mathrm{a}}$ & $5.5 \pm 0.05^{\mathrm{a}}$ & $41 \pm 0.4^{\mathrm{a}}$ & $15 \pm 0.4^{2}$ \\
\hline \multicolumn{6}{|c|}{ Leucophaeus pipixcan } \\
\hline Females (18) & $311 \pm 6.9$ & $4.2 \pm 0.12$ & $3.1 \pm 0.06$ & $28 \pm 0.3$ & $11 \pm 0.1$ \\
\hline Males (26) & $331 \pm 8.2$ & $4.2 \pm 0.11$ & $3.2 \pm 0.04$ & $29 \pm 0.3$ & $15 \pm 3.6$ \\
\hline Summer (13)* & $239 \pm 6.3$ & $3.9 \pm 0.07$ & $3.1 \pm 0.05$ & $28 \pm 0.2$ & $10 \pm 0.2$ \\
\hline Fall (44) & $323 \pm 5.8$ & $4.2 \pm 0.08$ & $3.2 \pm 0.04$ & $29 \pm 0.2$ & $13 \pm 2.1$ \\
\hline Overall (57) & $304 \pm 6.6^{\mathrm{b}}$ & $4.2 \pm 0.07^{\mathrm{b}}$ & $3.1 \pm 0.03^{\mathrm{b}}$ & $29 \pm 0.2^{\mathrm{b}}$ & $13 \pm 1.6^{b}$ \\
\hline
\end{tabular}

Table 2. Summary of heavy metal concentrations (dry weight, $\mu \mathrm{g} / \mathrm{g}$ ) in feathers from kelp (Larus dominicanus) and Franklin's (Leucophaeus pipixcan) gulls collected in Talcahuano, Chile during 2008 and 2009. Differences between species are denoted by asterisks (* $\mathrm{P}<0.05$;** $\mathrm{P}<0.005 ; * * * \mathrm{P}<0.0001)$. Males had significantly higher concentrations of mercury.

Resumen de concentraciones (peso seco, $\mu \mathrm{g} / \mathrm{g}$ ) de metales pesados en plumas de la gaviota dominicana (Larus dominicanus) y de Franklin (Leucophaeus pipixcan) muestreadas en Talcahuano, Chile en el 2008 y 2009. Diferencias entre especies se denota con asteriscos $(* \mathrm{P}<0,05$; $* * \mathrm{P}<0,005$; *** $\mathrm{P}<0,0001)$. La concentración de mercurio fue más alta en machos.

\begin{tabular}{|c|c|c|c|c|c|c|c|c|c|}
\hline \multirow[b]{2}{*}{ Metal } & \multicolumn{4}{|c|}{ Larus dominicanus } & \multicolumn{4}{|c|}{ Leucophaeus pipixcan } & \multirow[b]{2}{*}{ Min } \\
\hline & Sex & $\mathrm{N}$ & Mean $( \pm \mathrm{SD})$ & $\operatorname{Max}$ & Min & $\mathrm{N}$ & Mean $( \pm$ SD) & $\operatorname{Max}$ & \\
\hline \multirow[t]{3}{*}{ Arsenic } & F & 10 & $0.68 \pm 0.22$ & 1.03 & 0.36 & 13 & $0.55 \pm 0.24$ & 0.46 & 0.24 \\
\hline & M & 12 & $0.81 \pm 0.18$ & 1.08 & 0.43 & 12 & $0.73 \pm 0.47$ & 1.14 & 0.65 \\
\hline & Overall & & $0.75 \pm 0.21$ & & & & $0.64 \pm 0.37$ & & \\
\hline \multirow[t]{3}{*}{ Cadmium } & F & 10 & $0.02 \pm 0.01$ & 0.04 & $\mathrm{BDL}^{\mathrm{a}}$ & 13 & $0.18 \pm 0.27$ & 0.13 & 0.02 \\
\hline & M & 12 & $0.03 \pm 0.05$ & 0.15 & $\mathrm{BDL}$ & 12 & $0.11 \pm 0.07$ & 0.10 & 0.03 \\
\hline & Overall & & $0.03 \pm 0.04 *$ & & & & $0.15 \pm 0.20$ & & \\
\hline \multirow[t]{3}{*}{ Copper } & $\mathrm{F}$ & 10 & $17.1 \pm 14.7$ & 38.68 & 3.25 & 13 & $4.44 \pm 2.4$ & 5.90 & 4.80 \\
\hline & M & 12 & $21.5 \pm 13.4$ & 35.85 & 3.38 & 12 & $3.63 \pm 0.85$ & 4.46 & 2.41 \\
\hline & Overall & & $19.5 \pm 1.7^{* * *}$ & & & & $4.20 \pm 1.7$ & & \\
\hline \multirow[t]{3}{*}{ Lead } & $\mathrm{F}$ & 10 & $6.81 \pm 3.5$ & 10.00 & 1.22 & 13 & $4.2 \pm 7.9$ & 28.64 & BDL \\
\hline & M & 12 & $8.47 \pm 7.3$ & 27.6 & 1.00 & 12 & $2.00 \pm 0.83$ & 2.82 & 0.92 \\
\hline & Overall & & $5.97 \pm 6.0^{*}$ & & & & $2.57 \pm 5.5$ & & \\
\hline \multirow[t]{3}{*}{ Mercury } & $\mathrm{F}$ & 25 & $0.924 \pm 0.09$ & 1.64 & 0.40 & $20^{\mathrm{b}}$ & $1.45 \pm 0.46$ & 1.06 & 0.56 \\
\hline & M & 29 & $1.33 \pm 0.19^{* *}$ & 3.19 & 0.42 & $26^{\mathrm{b}}$ & $0.87 \pm 0.13$ & 1.00 & 0.61 \\
\hline & Overall & & $1.13 \pm 0.13$ & & & & $1.15 \pm 0.17$ & & \\
\hline
\end{tabular}

${ }^{\mathrm{a} B D L}=$ Below Detection Limit.

${ }^{\mathrm{b}} \mathrm{An}$ additional 13 birds were examined but could not be sexed. 
due to unequal exposure rates. It is plausible that increased exposure of kelp gulls to $\mathrm{Pb}$ and $\mathrm{Cu}$ is occurring via consumption of non-natural food items of anthropogenic origin and/or via inhalation.

Overall, metal levels in feathers of both kelp and Franklin's Gulls fell either below or within the range reported in feathers from the same species or from other marine birds. With the exception of one bird that had a mercury concentration of $9.33 \mu \mathrm{g} / \mathrm{g}$, levels were below those considered to be harmful in marine birds (Burger and Gochfeld 2002). Only one study has been published on heavy metal concentrations in feathers of Chilean seabirds (Ochoa-Acuña et al 2002). In this study, $\mathrm{Hg}$ in feathers of Franklin's gulls averaged $\sim 1.0 \mu \mathrm{g} / \mathrm{kg}$. The remaining Chilean studies have either reported egg or liver concentrations (Vermeer and Castilla 1991, Muñoz and Becker 1999, Cifuentes et al 2003). In the early 1980's, livers from kelp and Franklin's gulls sampled from El Chañaral, Atacama ( $900 \mathrm{~km}$ north of Talcahuano) from an area heavily polluted by tailings from a copper mine contained $\mathrm{Cu}$ and $\mathrm{Cd}$ concentrations ranging from 4.1 5.5 and $1.5-9.1 \mu \mathrm{g} / \mathrm{g}$, respectively (Vermeer and Castilla 1991). Kelp gulls sampled from Coquimbo $(\sim 800 \mathrm{~km}$ north of Talcahuano) had liver $\mathrm{Cd}$ and $\mathrm{Cu}$ concentrations ranging from $9.6-9.8$ and from $14.8-16.2 \mu \mathrm{g} / \mathrm{g}$, respectively (Cortes and Luna-Jorquera 2011). From studies conducted with these species elsewhere, feathers from kelp gulls sampled in southern Brazil contained $\mathrm{Cd}, \mathrm{Cu}$ and $\mathrm{Pb}$ concentrations that averaged $0.07,13$, and 7.5 $\mu \mathrm{g} / \mathrm{g}$, respectively (Barbieri et al 2010). Feathers from kelp gulls sampled from Namibia, South Africa, had average levels of $\mathrm{As}, \mathrm{Cd}, \mathrm{Hg}$ and $\mathrm{Pb}$ of 1.8, 1.4, 0.92, and $2.9 \mu \mathrm{g} / \mathrm{g}$, respectively (Burger and Gochfeld 1996). Franklin's gulls sampled from North America contained average feather levels that ranged between $0.13-4.1 ; 6.1$ ( $\mathrm{n}=1$ study); $0.40-1.1$; and $0.75-2.7 \mu \mathrm{g} / \mathrm{g}$ of $\mathrm{Cd}, \mathrm{Cu}$, $\mathrm{Hg}$, and $\mathrm{Pb}$, respectively (Burger 1996, Burger and Gochfeld 1996, Burger and Gochfeld 1999, Custer et al 2007).

In terms of gender differences, female kelp gulls had significantly lower $\mathrm{Hg}$ compared to males. This difference is likely due to transfer of $\mathrm{Hg}$ to eggs and has been reported previously from other avian species (Burger and Gochfeld 1992). The opposite (although not statistically significant) pattern was observed for Franklin's gulls (table 2). This makes sense since females were sampled in their wintering grounds prior to breeding. Similarly, Burger and Gochfeld (1996) found no gender differences in $\mathrm{As}, \mathrm{Cs}, \mathrm{Hg}$ and $\mathrm{Pb}$ in Franklin gulls sampled in their breeding grounds (Minnesota, USA).

In conclusion, the concentrations of heavy metals found in kelp and Franklin's gulls sampled from central Chile were generally comparable to values reported for these species sampled both from Chile and elsewhere in South America, North America and South Africa. Further, they fell below the levels that are known to cause adverse effects in seabirds. Differences in metal concen- trations between both species were not consistent and are likely due to a combination of differences in diet and timing of sampling in relation to molting.

\section{ACKNOWLEDGEMENTS}

This project was funded by a grant from the Chilean government awarded to D. González-Acuña (Fondecyt N¹070464). The authors would like to thank Pesquera Camanchaca Talcahuano and Sergio Valks Contreras, Teoboldo Navarrete Cubile and José Cuevas Díaz who granted us permission for capturing the gulls. We would also like to thank Dr. Sandra Briones from the Servicio de Salud de Talcahuano and Claudio Parraguéz from Talcahuano for granting permission for capturing birds for this study. We also thank Kevin Leet, Andrea Dowell, Charles Santerre and Karl Wood for their assistance with chemical analyses.

\section{REFERENCES}

Barbieri E, ED Passos, A Filippini, IS dos Santos, CAB Garcia. 2010. Assessment of trace metal concentration in feathers of seabird (Larus dominicanus) sampled in the Florianopolis, SC, Brazilian coast. Environ Monit Assess 169, 631-638.

Burger J. 1974. Breeding adaptations of Franklin's gull (Larus pipixcan) to a marsh habitat. Anim Behav 22, 521-567.

Burger J, M Gochfeld. 1992. Heavy metal and selenium concentrations in black skimmers (Rynchops niger) - Gender differences. Arch Environ Contam Toxicol 23, 431-434.

Burger J. 1996. Heavy metal and selenium levels in feathers of Franklin's Gulls in interior North America. Auk 113, 399-407.

Burger J, M Gochfeld 1996. Heavy metal and selenium levels in Franklin's gull (Larus pipixcan) parents and their eggs. Arch Environ Contam Toxicol 30, 487-91.

Burger J, M Gochfeld. 1997. Age differences in metals in the blood of herring (Larus argentatus) and Franklin's (Larus pipixcan) gulls. Arch Environ Contam Toxicol 33, 436440.

Burger J, M Gochfeld. 1999. Heavy metals in Franklin's gull tissues: Age and tissue differences. Environ Toxicol Chem 18, 673-678.

Burger J, M Gochfeld. 2002. Effects of chemicals and pollution on seabirds. In: Schreiber EA, J Burger (eds). Biology of Marine Birds. CRC Press, Boca Raton, Florida, USA, Pp 485-525.

Cifuentes JM, PH Becker, U Sommer, P Pacheco, R Schlatter. 2003. Seabird eggs as bioindicators of chemical contamination in Chile. Environ Pollut 126, 123-137.

Cortes M, G Luna-Jorquera. 2011. Effect of age and location in the concentration of cadmium and copper in the liver of the kelp gull Larus dominicanus. Rev Biol Mar Ocean 46, 287-292.

Custer TW, CM Custer, BA Eichhorst, D Warburton. 2007. Selenium and metal concentrations in waterbird eggs and chicks at agassiz national wildlife refuge, Minnesota. Arch Environ Contam Toxicol 53, 103-109.

González-Acuña D, C Barrientos, F Corvalán, J Lara, K Ardiles, D Doussang, C Mathieu, F Cerda, J López, R Ortega, J Torres, R Figueroa. 2010. Comparación de cuatro 
métodos de captura de gaviotas dominicanas (Larus dominicanus) en la ciudad de Talcahuano, Chile. Bol Chil Ornitol 16, 21-31.

González-Zevallos D. 2006. Seabird use of discards and incidental captures at the Argentine hake trawl fishery in the Golfo San Jorge, Argentina. Mar Ecol Prog Ser 316, 175-189.

Jaramillo A. 2005. Aves de Chile. Lynxs Editions. Barcelona, Spain.

ICES, International Council for the Exploration of the Sea. 1999. Seabirds as monitors of marine pollution. Report of the Working Group on Seabird Ecology. ICES, Copenhagen, Denmark.

Lasrado JA, CR Santerre, SM Shim, JR Stahl. 2005. Analysis of mercury in sportfish tissue by thermal decomposition, amalgamation/atomic absorption spectrophotometry. $J$ Food Protect 68, 879-881.

Ludynia K, S Garthe, G Luna-Jorquera. 2005. Seasonal and regional variation in the diet of the kelp gull in northern Chile. Waterbirds 28, 359-365.

Marinao CJ, P Yorio. 2011. Fishery discards and incidental mortality of seabirds attending coastal shrimp trawlers at Isla Escondida, Patagonia, Argentina. Wilson J Ornithol $123,709-719$.

Muñoz J, PH Becker. 1999. The kelp Gull as bioindicator of environmental chemicals in the Magellan region. A comparison with other coastal sites in Chile. Sci Mar 63, 495-502.
Ochoa-Acuña H, MS Sepúlveda, TS Gross. 2002. Mercury in feathers from Chilean birds: influence of location, feeding strategy, and taxonomic affiliation. Mar Pollut Bull 44, 340-345.

Petracci P, L La Sala, F Aguirre, G Perez, CH Acosta, N Sotelo, M Pamparana. 2004. Diet of the kelp gull (Larus dominicanus) during the breeding season in the Bahia Blanca estuary, Buenos Aires, Argentina. Hornero 19, 23-29.

United States Environmental Protection Agency. 2003. Methods for evaluating solid wastes, physical/chemical methods. Mercury in Solids and Solutions by Thermal Decomposition, Amalgamation, and Atomic Absorption Spectrophotometry SW-846 series, EPA method 7473.

Vermeer K, JC Castilla. 1991. High cadmium residues observed during a pilot study in shorebirds and their prey downstream from the El Salvador copper mine, Chile. Bull Environ Contam Toxicol 46, 242-248.

Villablanca R, G Luna-Jorquera, V H Marin, S Garthe, A Simeone. 2007. How does a generalist seabird species use its marine habitat? The case of the kelp gull in a coastal upwelling area of the Humboldt Current. ICES J Mar Sci 64, 1348-1355.

Weichler T, S Garthe, G Luna-Jorquera, J Moraga. 2004. Seabird distribution on the Humboldt Current in northern Chile in relation to hydrography, productivity, and fisheries. ICES J Mar Sci 61, 148-154. 